\title{
ANALISIS EFISIENSI BIAYA PERSEDIAAN MENGGUNAKAN METODE EOQ (ECONOMIC ORDER QUANTITY) PADA PT. XYZ
}

Analysis of Cost Efficiency on Inventory System Using EOQ (Economic Order Quantity) Method in The PT. XYZ

\author{
Dea Misbachul Umami ${ }^{1)}$, Mohammad Fuad Fauzul Mu'tamar ${ }^{1) *}$, Rakhmawati Rakhmawati ${ }^{1)}$ \\ ${ }^{1)}$ Jurusan Teknologi Industri Pertanian, Fakultas Pertanian, Universitas Trunojoyo Madura \\ Jalan Raya Telang Bangkalan, Kamal, Madura, Jawa Timur 69162 \\ *E-mail: mfuadfm@gmail.com
}

\begin{abstract}
Inventory control is one of the important things of working capital in a company. Economic Order Quantity (EOQ) could be decided from the safety stock, maximum inventory, and reorder point in a company. The aim of the research was to know the number of stock and inventory cost savings. The research used EOQ method on controlling the packaging cup $240 \mathrm{ml}$ and carton box to know the amount of safety stock, maximum inventory, and reorder point in PT. XYZ. The result showed that the sum of buying the material based on EOQ method in the 2015, 2016 and 2017.In the 2015 the amount $f$ packaging cup $240 \mathrm{ml}$ were 1.492 .031 cups, the amount $f$ carton box were 25.164 cartons, in the 2016 the sum of packaging cup $240 \mathrm{ml}$ were 1.492 .084 cups, the sum of cartoon box were 24.697 cartons, while in the 2017 the sum of packaging cup were 240 cups. Using the EOQ method can be known that inventory cost savings as the result of the decreasing of the order. Safety stock were around 447.406 for a $240 \mathrm{ml}$ cups and 9.319 for cartons box. Maximum inventory based on EOQ method were around 992.445 for $240 \mathrm{ml}$ cups and 20.549 for cartons. Reorder point based on EOQ method were around 860.066 for a $240 \mathrm{ml}$ cups and 17.918 for cartons.
\end{abstract}

Keywords: EOQ, inventory control, maximum inventory, reorder point, safety stock

\section{PENDAHULUAN}

Pengendalian persediaan merupakan salah satu modal kerja yang cukup penting dalam suatu perusahaan. Alasan yang mendasari perusahaan harus menentukan persediaan dengan tepat diantaranya adalah dengan adanya perencanaan persediaan, perusahaan dapat memenuhi pesanan pembeli secara cepat dan tepat, serta tidak akan menimbulkan persediaan berlebih yang dapat mengakibatkan penggunaan dana tidak efisien (Darmawan et al., 2015). Bahan baku merupakan salah satu factor yang cukup penting dalam dunia industri. Tanpa adanya bahan baku maka kegiatan industry tidak akan dapat berjalan.

Salah satu bahan baku pendukung yang cukup penting adalah kemasan. Kemasan biasanya terdiri dari kemasan dasar, kemasan tambahan dan kemasan pengiriman. Kemasan yang pada umumnya digunakan diantaranya adalah gelas, metal, kertas dan juga plastic. Masing-masing kemasan memiliki fungsi yang berbeda sehingga kemasan harus disesuaikan dengan bahan yang dikemas (Susetyarsih, 2012).

Dalam pengendalian persediaan baik bahan baku maupun produk jadi dapat dilakukan dengan menggunakan metode EOQ. Secara umum perhitungan menggunakan metode EOQ dipengaruhi oleh biaya pemesanan, biaya penyimpanan dan biaya pembelian. Biaya pemesanan diperoleh langsung dari perusahaan dengan total selama setahun. Biaya penyimpanan diestimasi berdasarkan ratarata penyimpanan barang selama satu tahun (Indroprastodan Erma 2012).

Dengan menggunakan metode EOQ maka dapat dihitung pula safety stock, 
maximum inventory dan juga reorder point yang optimal bagi perusahaan sehingga menghindari terjadinya kekurangan maupun kelebihan persediaan.

PT. XYZ merupakan perusahaan membuat terobosan dengan mendirikan bidang usaha manufaktur berupa "Air Minum Dalam Kemasan dengan merk "SWA". PT. XYZ pernah mengalami kekurangan bahan baku. Kekuranganbahan baku yang pernah terjadi salah satunya adalah pada kemasan cup $240 \mathrm{ml}$, seperti pada bulan September 2017 perusahaan memerlukan bahan baku cup $240 \mathrm{ml}$ sebanyak 1.520 .736 cup, namun bahan baku yang tersedia di gudang hanya 1.520.453 cup, sehingga kekurangan bahan baku tersebut membuat produksi terhambat selama satu hari untuk menunggu datangnya pesanan bahan baku berikutnya. Selain itu, perusahaan juga pernah mengalami kelebihan bahan baku kemasan karton box sehingga menyebabkan terjadinya pemborosan biaya persediaan bahan baku. Hal tersebut tejadi salah satunya ketika bulan Oktober 2017 dimana perusahaan harus melakukan produksi yang memerlukan karton box sebanyak 33.766 box, sedangkan bahan baku yang tersedia sebanyak 33.815 box. Jadi sisa bahan baku tersebut akan disimpan untuk digunakan sebagai persediaan, dan selama penyimpanan bahan baku maka ada biaya-biaya yang harus dikeluarkan demi menjaga kualitas bahan baku tersebut (Sumber: bagian produksi, Januari 2018).

Penelitian dilakukan dengan tujuan untuk menetapkan jumlah pembelian bahan baku kemasan cup $240 \mathrm{ml}$ dan karton box yang seharusnya dilakukan oleh PT. XYZ. Tujuan lainnya adalah untuk menentukan frekuensi pemesanan, biaya persediaan yang optimal, safety stock, maximum inventory dan juga reorder pointyang seharusnya dilakukan oleh PT. XYZ.

\section{METODE PENELITIAN}

Objek penelitian ini adalah PT. XYZ. Jenis data yang digunakan dalam penelitian adalah kebutuhan bahan baku per tahun, biaya pemesanan, biaya penyimpanan, dan lead time. Ada beberapa variable analisis perhitungan untuk mendukung penggunaan metode EOQ, yaitu sebagai berikut:

\section{Economic Order Quantity (EOQ)}

EOQ merupakan nilai jumlah bahan yang dibutuhkan selama setiap kali pembelian dengan menggunakan biaya paling ekonomis. Rumus yang digunakan dalam menghitung EOQ (Sugiono, 2009) adalah :

$$
\mathrm{EOQ}=\sqrt{\frac{2 \times D x S}{H}}
$$

Dimana :

D : Jumlah kebutuhan bahan per tahun

$S$ : Biaya pemesanan per order

$\mathrm{H}$ : Biaya penyimpanan per unit

\section{Total Inventory Cost (TIC)}

Total inventory cost merupakan perhitungan total persediaan bahan baku yang digunakan untuk mengetahui apakah perhitungan pembelian persediaan menggunakan metode EOQ lebih baik dibandingkan dengan metode konvensional perusahaan. Rumus yang digunakan untuk menghitung TIC adalah :

$$
\mathrm{TIC}=\sqrt{2 \times D \times S \times H}
$$

Dimana :

D : jumlah kebutuhan

$\mathrm{S}$ : Biaya pemesanan

$\mathrm{H}$ : Biaya penyimpanan per unit

\section{Safety Stock}

Safety stock merupakan metode yang berguna untuk melindungi perusahaan dari segala resiko yang dapat ditimbulkan dari adanya persediaan. Perhitungan safety stock didasarkan pada seberapa besar nilai penyimpangan yang terjadi terhadap rata-rata selama periode beberapa bulan terakhir. Nilai penyimpangan adalah standart deviasi 
yang dihitung dengan menggunakan rumus sebagai berikut :

Standart Deviasi $=\sqrt{\frac{\sum(X-\bar{x})^{2}}{n}}$

Dimana :

$\mathrm{n}$ : jumlah data

$\mathrm{x}$ : jumlah kebutuhan bahan

$\bar{x}$ : rata-rata kebutuhan bahan

Dari hasil standart deviasi tersebut dapat diketahui safety stock dengan menggunakan faktor pengaman 1,65 melalui rumus berikut:

Safety Stock $=S_{d} \times \mathrm{Z}$

Dimana :

$S_{d}:$ Standart Deviasi

$\mathrm{Z}$ : Faktor pengaman

\section{Maximum Inventory}

Maximum Inventory diperlukan oleh perusahaan agar jumlah persediaan yang ada di gudang tidak berlebihan sehingga tidak terjadi pemborosan modal kerja. Rumus yang digunakan untuk menghitung Maximum Inventory adalah sebagai berikut:

Maximum inventory $(\mathrm{MI})=$

$$
\text { Safety Stock + EOQ }
$$

Dimana :

Safety Stock : Persediaan pengaman

EOQ : jumlah pembelian optimal

\section{Re Order Point (ROP)}

Re Order Point (ROP) digunakan untuk memonitor barang persediaan, sehingga pada saat melakukan pemesanan barang kembali barang yang dipesan akan datang tepat waktu. Rumus yang digunakan untuk menghitung ROP adalah:

Reorder point $=$

$$
\text { safety stock + (lead time } \mathrm{x} \mathrm{Q})
$$

Dimana :

Safety stock : persediaan pengaman

Lead time : waktu tunggu

$\mathrm{Q}$ : jumlah penggunaan bahan baku ratarata per hari

\section{HASIL DAN PEMBAHASAN}

Selama ini PT. XYZ masih belum menggunakan metode EOQ untuk pengendalian persediaanya dan hanya melakukan perhitungan persediaan dengan cara sederhana, yaitu pemesanan bahan baku didasarkan pada jumlah permintaan produksi, dan pemesanannya dilakukan setiap 14 hari sekali, sehingga sering terjadi kelebihan maupun kekurangan bahan baku. Oleh karena itu, diperlukan perhitungan tertentu yang akurat dalam menentukan tingkat persediaan, salah satunya menggunakan perhitungan Economic Order Quantity (EOQ).

Pada penelitian ini dilakukan perhitungan EOQ menggunakan data 3 tahun terakhir yaitu mulai tahun 20152017. Data kebutuhan bahan baku selama 3 tahun terakhir ditampilkan pada Tabel 1.

Tabel 1. Kebutuhan bahan baku cup $240 \mathrm{ml}$ dan karton box PT. XYZ

\begin{tabular}{cccc}
\hline \multirow{2}{*}{ Tahun } & $\begin{array}{c}\text { Bahan Baku } \\
\text { Kemasan }\end{array}$ & $\begin{array}{c}\text { Kebutuhan } \\
\text { Bahan } \\
\text { Baku Per } \\
\text { Tahun } \\
\text { (unit) }\end{array}$ & $\begin{array}{c}\text { Frekuensi } \\
\text { Pemesanan }\end{array}$ \\
\hline \multirow{2}{*}{2015} & Cup 240 ml & 17.686 .176 & 21 \\
\cline { 2 - 4 } & Karton Box & 368.462 & 21 \\
\hline \multirow{2}{*}{2016} & Cup 240 ml & 17.691 .456 & 21 \\
\cline { 2 - 4 } & Karton Box & 368.572 & 21 \\
\hline \multirow{2}{*}{2017} & Cup 240 ml & 17.691 .504 & 21 \\
\cline { 2 - 4 } & Karton Box & 368.573 & 21 \\
\hline
\end{tabular}

Sumber: Bagian gudang bahan baku PT. XYZ

Pemesanan bahan baku dilakukan sebanyak 21 kali per tahun dengan lead time selama 7 hari. Setiap tahun kondisi ini dilakukan secara rutin tanpa mempertimbangkan perubahan lingkungan maupun kondisi produksi di perusahaan. 
Tabel 2. Biayapemesanan

\begin{tabular}{cccc}
\hline \multirow{2}{*}{ Tahun } & Produk & \multicolumn{2}{c}{ Biaya per Pesan } \\
\hline \multirow{2}{*}{2015} & & \multicolumn{2}{c}{$(\mathrm{S})$} \\
\cline { 2 - 4 } & Cup 240 ml & $\mathrm{Rp}$ & 232.143 \\
\hline \multirow{2}{*}{2016} & Karton Box & $\mathrm{Rp}$ & 152.143 \\
\cline { 2 - 4 } & Cup 240 ml & $\mathrm{Rp}$ & 257.619 \\
\hline \multirow{2}{*}{2017} & Karton Box & $\mathrm{Rp}$ & 162.619 \\
\cline { 2 - 4 } & Cup 240 ml & $\mathrm{Rp}$ & 262.857 \\
\cline { 2 - 4 } & Karton Box & $\mathrm{Rp}$ & 182.857 \\
\hline
\end{tabular}

Sumber: PT. XYZ

Biaya yang termasuk dalam biaya pemesanan adalah biaya telepon dan biaya administrasi. Jenis biaya diperhitungkan untuk menentukan seberapa besar penghematan yang akan didapatkan dengan menggunakan metode EOQ. Rincian biaya penyimpanan ditunjukkan pada Tabel 3.

Tabel 3. Biaya penyimpanan

\begin{tabular}{|c|c|c|c|}
\hline \multirow[t]{2}{*}{ Tahun } & \multirow[t]{2}{*}{ Produk } & \multicolumn{2}{|c|}{$\begin{array}{c}\text { Biaya Simpan per } \\
\text { Unit }\end{array}$} \\
\hline & & \multicolumn{2}{|c|}{$(\mathrm{H})$} \\
\hline \multirow{2}{*}{2015} & Cup $240 \mathrm{ml}$ & $\mathrm{Rp}$ & 3,69 \\
\hline & Karton Box & $\mathrm{Rp}$ & 177,05 \\
\hline \multirow{2}{*}{2016} & Cup $240 \mathrm{ml}$ & $\mathrm{Rp}$ & 4,09 \\
\hline & Karton Box & $\mathrm{Rp}$ & 196,53 \\
\hline \multirow{2}{*}{2017} & Cup $240 \mathrm{ml}$ & $\mathrm{Rp}$ & 4,50 \\
\hline & Karton Box & $\mathrm{Rp}$ & 216,07 \\
\hline
\end{tabular}

Sumber: PT. XYZ

Biaya yang termasuk dalam biaya penyimpanan adalah biaya listrik, biaya pengawasan dan perawatan. Tabel 4 menunjukkan perhitungan kebijakan perusahaan.
Tabel 4. Perhitungan kebijakan perusahaan

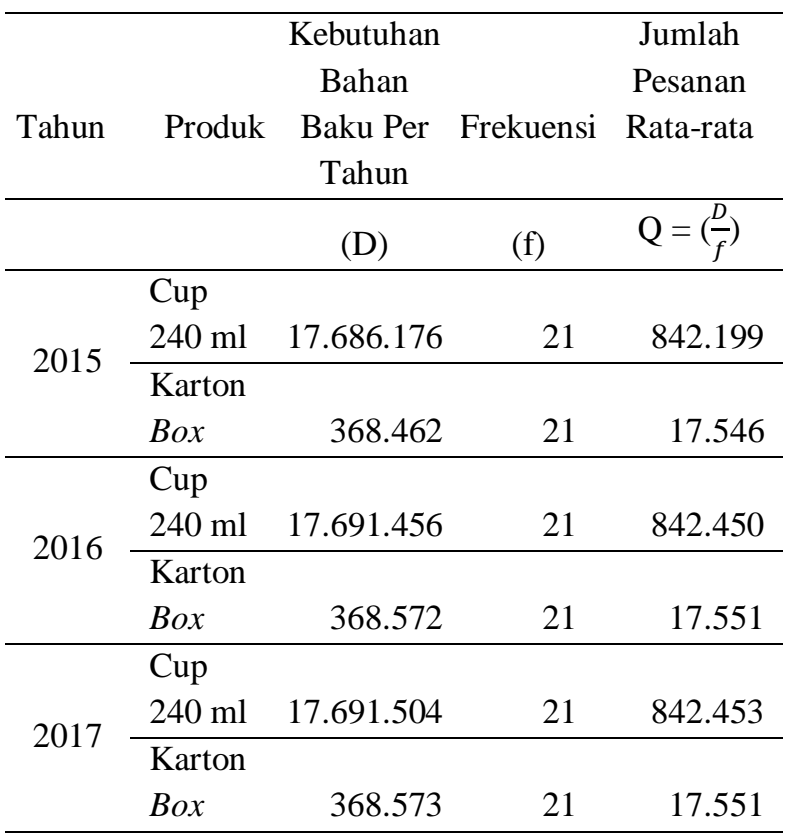

Tabel 4 menunjukkan bahwa terdapat pembelian bahan baku yang dilakukan oleh PT. XYZ pada tahun 2015 sampai 2017. Selain itu juga persediaan yang perlu dilakukan setiap satu kali pesan tidak terlalu berbeda jauh dari tahun ke tahun. Hal tersebut dikarenakan jumlah permintaan yang tidak mengalami kenaikan signifikan dan jumlah frekuensi pemesanan yang tidak berubah tiap tahun. Frekuensi pemesanan yaitu 21 kali. Tabel 5 menunjukkan data yang didapatkan apabila menggunakan perhitungan dengan metode EOQ.

Tabel 5. Perhitungan menurut metode EOQ

\begin{tabular}{|c|c|c|c|}
\hline Tahun & Produk & $\begin{array}{l}\text { Jumlah } \\
\text { Pesanan }\end{array}$ & Frekuensi \\
\hline & & $\mathrm{EOQ}=$ & \\
\hline & & $2 x D x S$ & $\overline{E O Q}$ \\
\hline & & $\sqrt{H}$ & \\
\hline \multirow{2}{*}{2015} & Cup $240 \mathrm{ml}$ & 1.492 .031 & 12 \\
\hline & Karton Box & 25.164 & 15 \\
\hline \multirow{2}{*}{2016} & Cup $240 \mathrm{ml}$ & 1.492 .084 & 12 \\
\hline & Karton $B o x$ & 24.697 & 15 \\
\hline \multirow{2}{*}{2017} & Cup $240 \mathrm{ml}$ & 1.437 .411 & 12 \\
\hline & Karton Box & 24.977 & 15 \\
\hline
\end{tabular}


Berdasarkan Tabel 5, jumlah pesanan semakin banyak dibandingkan dengan kebijakan perusahaan. Frekuensi pemesanan lebih jarang dilakukan oleh PT. XYZ yang dari awalnya 21 kali per tahun menjadi hanya 12 dan 15 kali dalam satu tahun.

Perhitungan total biaya persediaan menggunakan metode EOQ bertujuan untuk mencari nilai efisiensi yang mampu dihasilkan jika melakukan optimasi besaran persediaan perusahaan. Hasil perhitungan selengkapnya ditunjukkan pada Tabel 6.

Tabel 6. Penghematan biaya persediaan

\begin{tabular}{clccc}
\hline Tahun & Produk & $\begin{array}{c}\text { Kebijakan } \\
\text { Perusahaan } \\
(\mathrm{Rp})\end{array}$ & $\begin{array}{c}\text { EOQ } \\
(\mathrm{Rp})\end{array}$ & $\begin{array}{c}\text { Penghematan } \\
(\mathrm{Rp})\end{array}$ \\
\hline \multirow{2}{*}{2015} & $\begin{array}{l}\text { Cup } \\
240 \mathrm{ml}\end{array}$ & 6.428 .274 & 5.503 .530 & 924.744 \\
\cline { 2 - 5 } & $\begin{array}{l}\text { Karton } \\
\text { Box }\end{array}$ & 4.748 .274 & 4.455 .428 & 292.846 \\
\hline \multirow{2}{*}{2016} & $\begin{array}{l}\text { Cup } \\
240 \mathrm{ml}\end{array}$ & 7.134 .643 & 6.109 .114 & 1.025 .529 \\
\cline { 2 - 5 } & $\begin{array}{l}\text { Karton } \\
\text { Box }\end{array}$ & 5.139 .643 & 4.853 .722 & 285.920 \\
\hline & $\begin{array}{l}\text { Cup } \\
240 \mathrm{ml}\end{array}$ & 7.416 .131 & 6.470 .438 & 945.693 \\
\cline { 2 - 5 } & $\begin{array}{l}\text { Karton } \\
\text { Box }\end{array}$ & 5.736 .131 & 5.396 .719 & 339.412 \\
\hline
\end{tabular}

Tabel 6 menunjukkan bahwa pengendalian persediaan bahan baku di PT. XYZ dianggap layak untuk diterapkan sesuai dengan metode EOQ. Perusahaan dapat lebih menghemat biaya yang harus dikeluarkan untuk persediaan bahan baku khususnya kemasan cup $240 \mathrm{ml}$ dan karton box.

Menurut penelitian Sampeallo (2012), perhitungan total biaya persediaan menggunakan metode EOQ mampu memberikan efisiensi biaya. Hal tersebut karenakan dengan menggunakan metode EOQ nantinya akan didapatkan jumlah frekuensi pemesanan yang lebih optimal sehingga dapat menekan biaya pemesanan dan biaya penyimpanan persediaan.

\section{Safety Stock}

PT. XYZ selama ini menganggarkan safety stock untuk bahan baku kemasannya tidak terlalu tinggi dan hanya menggunakan perkiraan karena bahan baku dianggap mudah didapatkan kapan saja. Safety stock kemasan cup $240 \mathrm{ml}$ yang selama ini disediakan perusahaan hanya didasarkan pada perkiraan yaitu sekitar 150.000 cup, sedangkan untuk kemasan karton box sekitar 6500 karton. Selanjutnya akan dihitung besarnya safety stock menggunakan perhitungan melalui analisis penyimpangan. Dalam analisis penyimpangan, perusahaan juga harus menentukan seberapa jauh kondisi bahan baku yang masih dapat diterima. PT. XYZ menentukan batas toleransi yang masih bisa diterima yaitu sebesar 5\% dan serviceratio nya $95 \%$ sehingga faktor pengamannya adalah 1,65.

Perhitungan safety stock menurut metode EOQ dengan analisis penyimpangan untuk kemasan cup $240 \mathrm{ml}$ dan karton box tahun 2015 adalah sebanyak 447.382 cup dan 9.320 karton, tahun 2016 sebanyak 447.249 cup dan 9.318 karton, tahun 2017 sebanyak 447.286 cup dan 9.318 karton.

\section{Maximum Inventory}

Selama ini PT. XYZ menentukan maximum inventory untuk bahan baku kemasan didasarkan pada rata-rata jumlah bahan baku yang dipesan ditambah dengan safety stock. Tujuan dari dilakukannya perhitungan maximum inventory adalah agar perusahaan dapat menghindari terjadinya kekurangan atau kelebihan persediaan, karena kedua hal tersebut sangat mengganggu proses produksi maupun distribusi dan dapat berdampak pada kerugian perusahaan (Wardhani 2015). Maximum inventory menggunakan EOQ dapat dilihat pada Tabel 7. 
Tabel 8. Perhitungan reorder point

\begin{tabular}{|c|c|c|c|c|c|c|}
\hline Tahun & Produk & D & $\begin{array}{c}\mathrm{Q} \\
\text { (perhari) }\end{array}$ & $\begin{array}{l}\text { Lead } \\
\text { time }\end{array}$ & SS & ROP \\
\hline \multirow{2}{*}{2015} & Cup & 17.686 .176 & 58.954 & 7 & 447.382 & 860.059 \\
\hline & Karton & 368.462 & 1.228 & 7 & 9.320 & 17.918 \\
\hline \multirow{2}{*}{2016} & Cup & 17.691 .456 & 58.972 & 7 & 447.249 & 860.050 \\
\hline & Karton & 368.572 & 1.229 & 7 & 9.318 & 17.918 \\
\hline \multirow{2}{*}{2017} & Cup & 17.691 .504 & 58.972 & 7 & 447.286 & 860.088 \\
\hline & Karton & 368.573 & 1.229 & 7 & 9.318 & 17.919 \\
\hline
\end{tabular}

Tabel 7. Perhitungan maximum inventory

\begin{tabular}{|c|c|c|c|c|}
\hline Tahun & Produk & $\begin{array}{l}\text { Safety } \\
\text { Stock }\end{array}$ & EOQ & $\begin{array}{l}\text { Maximum } \\
\text { Inventory }\end{array}$ \\
\hline & & & & $\begin{array}{c}\text { EOQ + } \\
\text { Safety } \\
\text { Stock) }\end{array}$ \\
\hline \multirow{2}{*}{2015} & $\begin{array}{l}\text { Cup } 240 \\
\mathrm{ml}\end{array}$ & 447.382 & 1.492 .031 & 1.939 .413 \\
\hline & $\begin{array}{l}\text { Karton } \\
\text { Box }\end{array}$ & 9.320 & 25.164 & 34.485 \\
\hline \multirow{2}{*}{2016} & $\begin{array}{l}\text { Cup } 240 \\
\mathrm{ml}\end{array}$ & 447.249 & 1.492 .084 & 1.939 .333 \\
\hline & $\begin{array}{l}\text { Karton } \\
\text { Box }\end{array}$ & 9.318 & 24.697 & 34.015 \\
\hline \multirow{2}{*}{2017} & $\begin{array}{l}\text { Cup } 240 \\
\mathrm{ml}\end{array}$ & 447.286 & 1.437 .411 & 1.884 .697 \\
\hline & $\begin{array}{l}\text { Karton } \\
\text { Box }\end{array}$ & 9.318 & 24.977 & 34.295 \\
\hline
\end{tabular}

\section{Reorder Point}

Reorder Point (ROP) digunakan untuk memonitor barang persediaan, sehingga pada saat melakukan pemesanan barang kembali barang yang dipesan akan datang tepat waktu (Wijaya et al., 2013). PT. XYZ menjadwalkan reorder point hanya berdasarkan waktu dan perkiraan jumlah permintaan konsumen, sehingga pemesanan kembali akan dilakukan ketika persediaan di gudang mulai dirasa sedikit yang berjumlah sekitar 550.000 untuk kemasan cup dan 15.000 untuk kemasan karton. Tabel 8 menunjukkan perhitungan reorder point menurut metode EOQ.

\section{KESIMPULAN}

Jumlah pembelian bahan baku kemasan cup $240 \mathrm{ml}$ dan karton menurut perhitungan EOQ sebesar 17.691.504 cup $240 \mathrm{ml}$ dan karton box sebanyak 368.573 karton. Penghematan biaya persediaan sebesar 13,84\% sekitar Rp 57.645 untuk bahan baku kemasan cup $240 \mathrm{ml}$ per tahun dan bahan baku kemasan karton box sekitar 5,88\%. Jumlah safety stock sebesar 447.306, kemasan cup $240 \mathrm{ml}$ dan karton box sekitar 9.319 karton, dengan frekuensi pemesanan sebayak 15 kali dalam setahun. Selain itu didapatkan bahwa maksimum inventory sebesar 1.884.697 cup dan 34.295 karton box dengan reorder point sebesar 860.088 cup dan 17.919 karton.

\section{DAFTAR PUSTAKA}

Darmawan, G. A., Wayan C., Ni Nyoman Y. 2015. Penerapan economic order quantity (EOQ) dalam pengelolaan persediaan bahan baku tepung pada Usaha Pia Ariawan di Desa Banyuning Tahun 2013. E-Journal Bisma Universitas Pendidikan Ganesha, 3 (1): 1-10. 
Indroprasto dan Erma S. 2012. Analisis pengendalian persediaan produk dengan metode EOQ menggunakan algoritma genetika untuk mengefisiensikan biaya persediaan. Jurnal Teknik ITS, 1 (1): 305-309.

Sampeallo,Y. G. 2012. Analisis pengendalian persediaan pada UD. Bintang Furniture Sangasanga. Jurnal Eksis, 8 (1): 2032-2035.

Sugiono, A. 2009. Manajemen Keuangan untuk Praktisi Keuangan. Grasindo, Jakarta.

Susetyarsih, T. 2012. Kemasan produk ditinjau dari bahan kemasan, bentuk kemasan dan pelabelan pada kemasan pengaruhnya terhadap keputusan pembelian pada produk minuman mizone di Kota Semarang. Jurnal STIE Semarang, 4 (3): 19-28.

Wardhani, P. S. 2015. Perencanaan dan pengendalian persediaan dengan metode EOQ. Jurnal Media Mahardhika, 13 (3): 310-328.

Wijaya, A., Muhammad A., dan Tony S. 2013. Sistem informasi perencanaan persediaan barang. Jurnal Sistem Informasi, 2 (2): 14-20 